4. Кравець В. П. Історія гендерної педагогіки : [навч. посіб.] / В.П. Кравець. Тернопіль: Джура, 2005. - 440 с.

5. Літературознавча енциклопедія: [автор-уклад. Ю. І. Ковалів]. - К.: Академія, 2007. - T.1. $-608 \mathrm{c}$.

Стаття надійшла до редакції 12.05.2012 p.

УДК 378.621

С. О. Кононенко,

кандидат пед. наук, доиент, Кіровоградський ДПУ імені В. Винниченка

\title{
ОСОБЛИВОСТІ ВИВЧЕННЯ ЕЛЕКТРОТЕХНІЧНИХ РОБІТ У 7-9 КЛАСАХ ОСНОВНОЇ ШКОЛИ
}

Кононенко С. О. Особливості вивчення електротехнічних робіт у 7-9 класах основної иколи.

У статті запропоновано методику викладання електротехнічних робіт для учнів 7-9 класів під час вивчення курсу «Технологї̈» відповідно до чинної нової редакиії навчальної програми.

Ключові слова: методика, електротехніка, технології, електротехнічні роботи.

Кононенко С. А. Особенности изучения электротехнических работ в 7-9 классах основной школьь.

В статье предложена методика изучения электротехнических работ для учеников 79 классов при освоении курса «Технологии» в соответствии к действующей новой редакиии учебной программы.

Ключевые слова: методика, электротехника, технологии, электротехнические работьы.

Kononenko S. Features of the study of electrical work in grades 7-9 of basic school.

In the article the offered methodology of teaching of electrical engineering works is for students 7-9 classes at the study of course of "Technology" in accordance with the operating new release of online tutorial.

Key words: methods, electrical technology, electrical work.

Постановка проблеми. Зміст варіативної частини нової редакції шкільної навчальної програми з трудового навчання передбачає вивчення електротехнічних робіт за двома варіантами у 5-6 та 7-9 класах [2]. Це пов'язано 3 тим, що процес вивчення електротехнічних робіт має певні свої особливості.

По-перше, електротехнічні роботи займають провідне місце в системі загально-технічної підготовки учнів, оскільки в процесі їх вивчення створюються умови для виконання основних завдань трудового навчання. Успішно проводиться профорієнтаційна робота у формі бесід про професії людей, пов'язаних з електрикою. Оскільки електрична енергія знаходить широке використання в народному господарстві, то, пов'язані з нею професії $\epsilon$ досить поширеними (професії електромонтера, слюсаряелектромонтажника та інші). Розповідь про ці професії органічно вписується до змісту навчального матеріалу.

По-друге, поняття «електрична енергія» наскрізно пронизує сучасне виробництво, становить його суттєві ознаки. Тому шляхом ознайомлення 3 ним створюються уявлення про основи сучасного виробництва в цілому, тобто здійснюється реалізація політехнічного навчання. 
По-третє, в процесі вивчення учнями електротехнічних робіт проводиться велика виховна робота. Формується почуття патріотизму на основі тих успіхів, що має наша країна у цій галузі, за умови, якщо вчитель приділяє цьому достатню увагу. Значні можливості створюються і для економічного виховання на основі формування уявлень про економію електроенергії тощо [1].

Сказане пояснює, чому вивчення електротехнічних робіт передбачено для варіативних модулів навчальних програм у 7-9 класах. Час на це відводиться незначний, а обсяг знань і вмінь досить великий. У зв'язку з цим має бути особливий підхід щодо змісту навчання і розроблення проведення занять. Розв'язуючи ці питання, вчителю слід ураховувати, що електротехнічні роботи випереджають вивчення електрики з курсу фізики. Тому учні не мають відповідних теоретичних знань і спрямованість занять має бути суто практичною. Не слід підмінювати курс фізики. У цьому випадку має місце випадок, коли трудове навчання формує в учнів практичний досвід, теоретичне усвідомлення якого відбудеться пізніше під час вивчення фізики.

Метою статті $\epsilon$ розроблення сучасної методики навчання учнів електротехнічним роботам 3 урахуванням методичних особливостей притаманних вивченню трудового навчання.

Виклад основного матеріалу. Аналізуючи зміст розділу «Електротехнічні роботи» у 5-6 та 7-9 класах виокремлюють такі питання: електрична енергія в господарстві держави; облік та планування заходів щодо економного використання електроенергії; джерела та споживачі електричної енергії, провідники та ізолятори, проводи та їх види, електромонтажні інструменти та порядок роботи 3 ними; електричне коло, побутова електроарматура та запобіжники, побутові електроприлади; електробезпека, ознайомлення 3 професією електрика. Розглядаючи методику навчання електротехнічним роботам у 7-9 класі, доцільно говорити окремо про питання що вивчаються лише у цих класах, так як вони мають специфічні особливості, а саме: альтернативні джерела електроенергії, паралельне та послідовне з'єднання, колекторний двигун, елементи автоматики.

На початку вивчення розділу варто зазначити, що альтернативні джерела енергії - це поновлювані джерела, до яких відносять енергію сонячного випромінювання, вітру, морів, річок, біомаси, теплоти Землі, вторинні енергетичні ресурси, які наявні постійно або виникають періодично у довкіллі.

Під час вивчення вказаного питання необхідно сформувати в учнів уявлення про їх види та можливості одержання. Слід також звернути увагу на їх переваги та недоліки. Для цього доцільно вчителеві використовувати різноманітну наочність, яка б містила не лише відеофільми чи плакати 3 певної теми, а й демонстрації найпростіших фізичних дослідів і прикладів використання їх в техніці та побуті.

Паралельне та послідовне з'єднання споживачів. Для пояснення сутності паралельного з'єднання споживачів варто скористатися тким дослідом. До батареї гальванічних елементів, за допомогою провідників приєднують 
електричну лампу через вимикач, замкнувши коло, учні спостерігають за світінням електричної лампи, що свідчить про надходження електричної енергії від джерела струму до споживача. Далі, беруть ще одну електричну лампу і приєднують іiі до першої електричної лампи, у такий спосіб, щоб їх гвинтові контакти та центральні контакти відповідно, були з'єднані один 3 одним. У результаті учні спостерігають таке ж саме яскраве світіння обох ламп. 3 цього роблять висновок: так як кожен споживач електричної енергії має два контакти, то їх умовно можна позначити: один знаком «+», другий знаком «-». Якщо всі контакти $з$ маркуванням «+» поєднати в одній точці, а всі контакти 3 позначкою «-» - в іншій, то таке з'єднання називається паралельним. Однією з особливостей такого кола буде те, що кожен із споживачів буде працювати нормально лише за тих умов, коли до нього буде надходити відповідна кількість енергії, а це призведе до того, що зі збільшенням кількості споживачів буде збільшуватися потік електричної енергії.

Послідовне з'єднання демонструють за допомогою такої установки. До джерела струму приєднують електричну лампу, замкнувши коло учні спостерігають за іï світінням. Далі розривають коло, роз'єднавши один 3 провідників від споживача до лампи, i в цей розрив вмикають ще одну лампу. Замкнувши коло, учні спостерігають за тим, що яскравість ламп значно зменшилась. Так, з’єднання, коли кожна клема 3 позначкою «-» першого споживача з'єднується 3 клемою 3 позначкою «+» іншого споживача називають послідовним.

Робиться висновок про те, що за такого з’єднання споживачів здатність їх виконувати аналогічну роботу зменшується. Далі розривають коло між джерелом електричного струму та споживачем і додають до нього ще один такий самий послідовно сполучений гальванічний елемент. Замкнувши електричне коло, учні знову спостерігають яскраве сяяння обох ламп. Роблять висновок, щоб збільшити можливість виконувати роботу, необхідно збільшувати енергію джерела електричного струму.

Контрольно-вимірювальні прилади. Відповідно до чинної програми [2] учні 7-9 класів вивчають контрольно-вимірювальні прилади, що використовуються при проведені електротехнічних робіт. Авторами підручника [3] запропоновано розгляд таких питань, присвячених вивченню контрольно-вимірювальних приладів: принцип дії і будова контрольно-вимірювальних приладів, системи вимірювальних приладів, лічильник електроенергії, неоновий пробник, амперметр, вольтметр і авометр. Проте сьогодення вносить певні корективи до нашого життя, а саме розвиток техніки i технологій надає змогу упровадження у виробництво та побут сучасної електронної техніки: стрілочні (аналогові) прилади замінюються цифровими приладами, індукційні лічильники замінюються на електронні, у повсякденній роботі електрослюсарі використовують частіше покажчики напруги, ніж окремі вольтметри тощо.

До основних положень під час вивчення контрольно-вимірювальних приладів ми винесли наступні: учні повинні засвоїти використання як стрілочних, так i цифрових електровимірювальних приладів, уважаємо 
недоцільним вивчення систем вимірювальних приладів у шкільному курсі технології, оскільки їх вивчення вимагає суттєвих фізичних знань i, крім того, вивчення систем вимірювальних приладів дублюється в курсі фізики, замість вивчення індукційного лічильника електроенергії доцільно розглянути принцип роботи електронного лічильника, а замість авометра - принцип дії цифрового мультиметра та покажчиків напруги.

Колекторний двигун. Вивчення учнями будови та принципу роботи універсального колекторного двигуна зумовлено тим, що такі двигуни набули широкого використання в техніці; це електродрилі, електролобзики, електрорубанки, шуруповерти та інші. У побуті це: кавомолки, міксери, електром'ясорубки, блендери, кухонні комбайни.

Зрозуміло, що для пояснення принципу роботи колекторного двигуна учням необхідно мати певні фізичні знання, які їм потрібні для засвоєння нового навчального матеріалу. Розв’язуючи це питання, слід спиратися на ті знання, які мають учні під час вивчення попереднього навчального матеріалу, їхнього життєвого досвіду та деяких пропедевтичних досліджень, за допомогою яких учні засвоять новий навчальний матеріал.

Для пояснення принципу роботи колекторного двигуна потрібно звернутись до найпростішого у методичній літературі досліду з визначення дії сили на провідник зі струмом у магнітному полі. Спочатку складають найпростіше електричне коло 3 джерела живлення та провідника, приєднаного до нього (таке коло учні вивчили ще в п'ятому класі). Далі беруть постійний магніт, з його властивостями учні ознайомлені з життєвого досвіду, і підносять його до провідника зі струмом. Слід зауважити що краще щоб провідник був підвішеним за допомогою ниток до штативу. Чим ближче ми будемо наближати магніт до провідника, тим сильніше він буде діяти на нього, відштовхуючи провідник в ту чи іншу сторони. Цим же дослідом можна скористатися для визначення напряму дії сили на провідник. Для цього учням повідомляють такі умови: якщо постійний магніт розташувати Отже, щоб північний полюс був зверху, а південний знизу, а між полюсами постійного магніту розташувати провідник зі струмом так, щоб струм ішов зліва направо, то на провідник буде діяти сила, спрямована від спостерігача.

Надалі доцільно скористатися моделлю колекторного двигуна, яку можна виготовити власноруч або скористатися готовою, яка $є$ у фізичному кабінеті, i на їі прикладі продемонструвати принцип дії двигуна та звернувши увагу учнів на основні вузли приладу. Демонстрацію слід підтримати наочним зображенням принципової схеми колекторного двигуна, 3 тією відмінністю що замість постійних магнітів у ній використано електромагніти, так, як це реалізується у справжніх промислових колекторних двигунах.

Елементи автоматики. Матеріал про елементи автоматики має велике значення для формування в учнів уявлення про основи сучасного виробництва. Автоматизація та комплексна механізація виробничих процесів звільняє людину від виконання основних та допоміжних рухів. Функції 
робітників зводяться при цьому до налагодження та контролю за роботою механізмів і пристроїв, що забезпечують виконання певних робіт.

Створення автоматичних ліній, цехів та заводів дає робітникові можливість керувати рядом агрегатів. За таких умов керування і контроль за роботою обладнання здійснюється з одного пункту. С два способи керування та контролю на відстані: дистанційний і телемеханічний.

За дистанційного керування команди подаються кожному виконавчому органу окремими каналами.

Останнім часом все ширше застосовуються системи телемеханічного керування та сигналізації. Вони характеризуються тим, що лінії зв'язку «ущільнюються»: ними передається значна кількість різних команд, тобто одна лінія зв'язку може обслуговувати значну кількість об'єктів. Щоб розрізняти сигнали, імпульсам струму надають різних якісних характеристик.

Телемеханічна система забезпечує зворотний зв'язок між керованими об'єктами та пультом керування, тобто контроль за ходом роботи. Тому застосовують iї тоді, коли безпосереднє спостереження за робочим процесом неможливе. Так, під час прокатування металів у ливарному виробництві на великих металорізальних верстатах застосовують промислові телевізійні установки.

Автоматизація забезпечує виконання без участі людини таких основних функцій, як контроль, керування, захист та регулювання.

Щоб автоматично керувати технологічним процесом, застосовують різні пристрої, які забезпечують увімкнення робочих органів верстата у певній послідовності або за певною програмою. Тому автоматичне керування називають ще і програмним.

Автоматичний захист необхідний для попередження можливих аварій, браку у зв'язку з порушеннями роботи машини або технологічного процесу.

Автоматичне регулювання полягає в тому, що в процесі роботи автоматично підтримується на одному рівні певний чинник виробничого процесу. Таким чинником може бути температура, тиск, швидкість та ін.

Здійснити кожну з функцій автоматизації процесів можна завдяки застосуванню відповідних пристроїв. Вони у свою чергу зв'язуються між собою механічним, електричним та іншими способами, утворюючи систему автоматичного керування. Йдеться не лише про забезпечення послідовності виконання технологічного процесу (програмне керування), а й про контроль, захист та регулювання. Проте не в кожному виробничому процесі необхідно виконувати всі можливі функції автоматизації. Тому системи автоматичного управління можуть бути більш або менш складними.

Кожну систему автоматичного керування можна подати структурною схемою, що показує, з яких елементів складається система та зв'язок між ними.

Перший елемент - програмоносій, на якому «записано» програму роботи. Звідси надходять сигнали, що показують, у якій послідовності та коли треба виконати роботу. За походженням сигнали можуть бути механічними, електричними та ін. Далі їх сприймає блок керування i 
передає у вигляді команди на виконавчий пристрій. За необхідності команди підсилюються за допомогою спеціальних підсилювачів.

Команди проходять через пристрій захисту. Ті з них, які не виходять за межі, передбачені режимом роботи машини та технологічним процесом, передаються, на виконавчий пристрій. В інших випадках команда затримується, а сигнал про це поступає на блок керування. У такий спосіб здійснюється зворотний зв'язок між пристроєм захисту та блоком керування.

Виконавчий пристрій виконує необхідні дії, що забезпечують заданий вплив на керований об'єкт. Результати впливу перевіряються вимірювальними пристроями, через які знову-таки забезпечується зворотний зв'язок з блоком керування та відповідне коригування команд.

Застосовують системи автоматичного керування 3 однаковими структурними схемами. Щоб мати загальне уявлення про суть автоматизації виробничих процесів, не треба ознайомлювати учнів 3 усіма видами виробництва. Достатньо розглянути це питання на певному конкретному прикладі. До цього слід додати, що системи автоматичного керування в різних галузях промисловості та сільського господарства не лише мають однакову структурну схему, а й складаються 3 тих самих пристроїв та механізмів, що входять до складу їх елементів. Так, до блоку керування входять різноманітні реле, вимірювальні пристрої, датчики, електро-, гідроi пневмодвигуни тощо [1].

Добираючи об’єкти роботи для учнів, слід керуватися таким: вироби повинні бути доступними для розуміння та викликати в учнів інтерес; технологія виготовлення їх має враховувати обладнання навчальних майстерень і передбачати можливість використання набору деталей або напівфабрикатів; під час практичної роботи учні повинні брати активну участь у плануванні, обговоренні конструкції виробу, складанні його структурної схеми та технології виготовлення. Варто також зауважити, що вивчення різноманітних датчиків методично себе не виправдовує, доцільно ознайомлювати учнів лише з тими які їм будуть зрозумілими. Наприклад, терморегулятор електропраски, вимикач з поплавком тощо.

Програмою передбачено ознайомлення учнів 3 напівпровідниковим діодом. Тому учителю потрібно, не розкриваючи суті фізичних процесів, що лежать в основі роботи напівпровідникових приладів, ознайомити учнів лише із застосуванням діодів у техніці. Він демонструє напівпровідникові діоди різних типів та розшифровує їх маркування.

Під час дослідів учитель розкриває основну властивість діода пропускати електричний струм в одному напрямі. Для демонстрування принципу роботи діоду доцільно скласти просте електричне коло, яке складається 3 джерела струму (батарейка від кишенькового ліхтарика), лампи розжарювання напругою 3,5 В 3 робочим струмом 0,5-1,0 А та напівпровідникового діоду увімкнених послідовно, також важливо передбачити можливість перемикання діоду так, щоб учням було зрозуміло коли він увімкнений у прямому, а коли у зворотному напрямі. 
Оскільки учні ще не вивчали змінного струму та принцип роботи трансформатора, ми вважаємо недоцільним вивчення будови різноманітних випрямлячів, а звернути лише їх увагу на використання діодів у випрямлячах.

Висновки. Запропонована методика вивчення електротехнічних робіт учнями 7-9 класів передбачає як традиційні підходи до вивчення навчального матеріалу, так і нові. Головною відмінністю $є$ те, що матеріал вивчається без використання фундаментальних фізичних знань учнів 3 основ наук, які вивчаються у школі. Спираючись на життєвий досвід учнів та методичні розробки, з'являється можливість вивчення вказаного матеріалу учнями, яка повною мірою задовольняє усі вимоги щодо вивчення електротехнічних робіт.

\section{Література}

1. Тхоржевський Д.О. Методика трудового i професійного навчання та викладання загально технічних дисциплін: [навч. посіб.]. - 3-є вид., перероб. і допов.] / Д.О. Тхоржевський. - К.: Вища шк., 1992. - 334 с.

2. Навчальна програма «Трудове навчання. 5-9 класи» / за загальною редакцією В.М. Мадзігона. - К.: Вища школа, 2001. - 178 с.

3. Терещук Б.М. Трудове навчання. Техн. види праці: [підруч. для 8 кл. загальноосвіт. навч. закладів] / Б.М. Терещук. - К.: «Видавництво «Арка», 2005. - 208 с.

Стаття надійшла до редакції 12.05.2012 p.

УДК: 372.4.035.3.

О. Д. Літковець, ст. викладач, Рівненський державний гуманітарний університет

\section{ДОСЛІДЖЕННЯ МІЖПРЕДМЕТНИХ ЗВ'ЯЗКІВ У ФОРМУВАННІ ГРАФІЧНИХ УМІНЬ В УЧНІВ ПОЧАТКОВИХ КЛАСІВ}

Літковець О.Д. Дослідження міжпредметних зв'язків у формуванні графічних умінь в учнів початкових класів.

Статтю присвячено дослідженню міжпредметних зв 'язків у формуванні графічних умінь в учнів початкових класів.

Ключові слова: графічні уміння, міжпредметні зв'язки, графічна діяльність.

Литковеи Е.Д. Исследования межпредметных связей в формировании графических умений у учеников начальных классов.

Статья посвящена исследованию межпредметных связей в формировании графических умений в учеников начальных классов.

Ключевые слова: графические умения, межпредметные связки, графическая деятельность

Litkovets E. Studies of interdisciplinary relationships in the formation of graphic skills to primary school students.

The article is sanctified to research of intersubject connections in forming of graphic abilities for the students of initial classes.

Key words: graphic abilities, intersubject copulas, graphic activity.

Актуальність та постановка проблеми. Проблема міжпредметних зв’язків є однією із найважливіших у педагогіці, що зумовлено насамперед сучасними процесами інтеграції та диференціації наукових i технічних галузей діяльності людини. 